\title{
Toward Developing a Preventive MERS-CoV Vaccine-Report from a Workshop Organized by the Saudi Arabia Ministry of Health and the International Vaccine Institute, Riyadh, Saudi Arabia, November 14-15, 2015
}

\author{
Jean-Louis Excler, Christopher J. Delvecchio, \\ Ryan E. Wiley, Marni Williams, In-Kyu Yoon, \\ Kayvon Modjarrad, Mohamed Boujelal, \\ Vasee S. Moorthy, Ahmad Salah Hersi, \\ Jerome $\mathrm{H}$. Kim, on behalf of the \\ MERS-CoV Vaccine Working Group ${ }^{1,2}$
}

Middle East respiratory syndrome (MERS) remains a serious international public health threat. With the goal of accelerating the development of countermeasures against MERS coronavirus (MERS-CoV), funding agencies, nongovernmental organizations, and researchers across the world assembled in Riyadh, Saudi Arabia, on November $14-15,2015$, to discuss vaccine development challenges. The meeting was spearheaded by the Saudi Ministry of Health and co-organized by the International Vaccine Institute, South Korea. Accelerating the development of a preventive vaccine requires a better understanding of MERS epidemiology, transmission, and pathogenesis in humans and animals. A combination of rodent and nonhuman primate models should be considered in evaluating and developing preventive and therapeutic vaccine candidates. Dromedary camels should be considered for the development of veterinary vaccines. Several vaccine technology platforms targeting the MERS-CoV spike protein were discussed. Mechanisms to maximize investment, provide robust data, and affect public health are urgently needed.

$\mathrm{M}$ iddle East respiratory syndrome (MERS) remains a serious public health threat within Saudi Arabia and internationally, as recently illustrated by an outbreak in South Korea with potential pandemic risk (1-7). A vaccine (or vaccines) targeting the MERS coronavirus (MERS-CoV),

\footnotetext{
Author affiliations: International Vaccine Institute, Seoul,

South Korea (J.-L. Excler, I.-K. Yoon, J.H. Kim); Shift Health,

Toronto, Ontario, Canada (C.J. Delvecchio, R.E. Wiley,

M. Williams); Walter Reed Army Institute of Research, Silver

Spring, Maryland, USA (K. Modjarrad); King Abdullah International Medical Research Center, Riyadh, Saudi Arabia (M. Boujelal); World Health Organization, Geneva, Switzerland (V.S. Moorthy); Ministry of Health, Riyadh (A.S. Hersi)
}

DOI: http://dx.doi.org/10.3201/eid2208.160229 which causes the disease, will be a critical component of future public health prevention measures $(8-10)$. With the goal of accelerating the development of countermeasures against MERS-CoV, funding agencies, nongovernmental organizations, and researchers across the world assembled in Riyadh, Saudi Arabia, on November 14-15, 2015, to discuss current data and research progress to enhance understanding of disease progression from MERS-CoV infection, vaccine development, the challenges of developing treatment measures (e.g., unclear disease mechanisms and transmission patterns), preclinical development and animal models, the landscape of emerging technologies and scientific platforms, and considerations for clinical development. One primary objective of the meeting was to articulate a coordinated action plan that aligns efforts and resources. The meeting was spearheaded by the Ministry of Health $(\mathrm{MOH})$ of Saudi Arabia and co-organized by the International Vaccine Institute, Seoul, South Korea.

\section{Development of MERS-CoV Animal Models}

When developing countermeasures against MERS-CoV infection, rodents and small animal models that mimic human disease hallmarks would be useful in initial screening studies before the measure is tested in larger animals (e.g., nonhuman primates and, potentially, camels). Although upper respiratory tract disease develops more severely in the latter (11), studying immune correlates of protection and vaccine efficacy in camels (the only natural host besides bats and humans identified thus far) may reveal vulnerabilities of MERS-CoV that may be exploited for human vaccine strategies.

The development of MERS vaccines faces several challenges. Existing small animal species do not naturally express the primary receptor that MERS-CoV uses to infect humans, the human dipeptidyl-peptidase 4 (hDPP4)

${ }^{1}$ MERS-CoV Vaccine Working Group: Adam Cockrell, Reed Johnson, Vincent Munster, Chien-Te Tseng, James Cummings, Lanying Du, Larry Ellingsworth, Luis Enjuanes, Andrea Gambotto, Sarah Gilbert, Bart Haagmans, Shibo Jiang, Christos Kyratsous, Wayne Marasco, Joel Maslow, Michael Muehlebach, Gerd Sutter, Linqi Zhang, Hail Alabdaly, Peter Hotez, Ibrahim Juffali, Ji-Young Min, Rafick-Pierre Sékaly, Erik Stemmy.

${ }^{2}$ All authors contributed equally to this article. 
receptor (12-19). This lack results in the animal's inability to sustain infection and for clinical illness to develop from MERS-CoV. Larger animal models, such as nonhuman primates, have not yet been optimized to consistently mimic the disease patterns observed in human infection (which is incompletely understood) and also have associated logistical challenges because that work must be completed in Biosafety Level 3 facilities.

Mouse DDP4 cannot support MERS-CoV infection (16). Although efforts have been made to adapt MERSCoV itself to exhibit human disease phenotypes in rodents, greater success has been achieved through the development of specialized mouse models that express hDPP4 (20-22). Mouse strains that globally express hDPP4 are susceptible to infection by MERS-CoV, and the mice display lower respiratory tract infection, weight loss, and increased respiratory rate, but also encephalitis, which makes the strains highly lethal. Human DPP4 expression is, however, transient and limited to the lung after Ad5-hDPP4 transduction by intranasal inoculation (21). These infected transgenic mice exhibit transcriptional activation of genes encoding classic antiviral cytokines (interferon [IFN]- $\beta$, IFN- $\gamma$, and MX-1) and pro-inflammatory cytokines (interleukin [IL]-2, IL-6, IL-12, p40, IL-1- $\alpha$, and tumor necrosis factor $[\mathrm{TNF}]-\alpha$ ), as well as chemokines (granulocyte-colony stimulating factor [G-CSF], monocyte chemoattractant protein-1 [MCP-1], interferon gamma-induced protein 10 [IP10], CXC motif ligand 1 [CXCL-1], macrophage protein 1 [MIP-1], and chemokine (C-C motif) ligand 5 [CCL5 or RANTES]), in contrast with the negligible gene activation of infected nontransgenic mice. IL-1, IL-6, TNF- $\alpha$, G-CSF, MCP-1, IP-10, CXCL-1, MIP-1, RANTES, and interferoninduced GTP-binding protein (MX-1) have been detected in the lungs and brains of infected transgenic mice (20).

However, formation of hybrid mouse-human DPP4 dimers in transgenic mice could affect immune regulation and lead to poorly understood outcomes that could confuse the interpretation of disease natural history and vaccine efficacy. Alternatively, a minimally modified version of mouse DPP4, by mutation of 2 amino acids, can support MERS-CoV infection. Mice with this mutation experience severe lower respiratory tract infection, although they do not exhibit brain infection (16). In addition, Pascal et al. have developed mice that express hDPP4, under the control of its endogenous promoter and the $3^{\prime}$ untranslated region, and show lung-specific infection and inflammation (22). Further testing may prove that vaccine evaluation in these small animal models could lead to a better understanding of immunogenicity and efficacy of vaccine candidates and the therapeutic measures being considered for evaluation in larger animals and humans.

Among current nonhuman primate models, rhesus macaques display mild-to-moderate clinical signs on viral challenge (23), whereas the common marmoset is reported to exhibit more severe signs of infection $(24,25)$ and could be a better model for the severe clinical syndrome observed in MERS-CoV-infected persons. However, not all research groups have been able to replicate severe disease outcomes in marmosets. Factors contributing to this could include variations in physical location, age, and origin of the marmosets; challenge virus strains and stocks; route and dose of inoculation; and in protocols. To be able to provide robust and reproducible outcomes, these nonhuman primate models need additional development, optimization, and standardization.

Camels are also being used to evaluate MERS-CoV infection, and findings from Adney et al. showed that these animals are unique in that they experience an upper respiratory tract infection. Although we do not know the efficiency of airborne versus droplet or another mode of transmission, viral shedding from the upper respiratory tract might explain the efficiency of camel-camel and camel-human transmission $(11,26)$. Although camels do not display the severe disease symptoms observed in infected humans (26), a camel infection model remains useful for understanding the disease in camels and identifying potential immune correlates of protection induced by vaccination. Veterinary countermeasures could form part of a One Health strategy to forestall zoonotic transmission to humans (1). Hesitation to implement animal vaccination strategies in camels once a vaccine becomes available can be attributed to the absence of severe disease in camels (only upper respiratory tract infection with rhinitis) and to skepticism among key groups regarding zoonotic transmission of MERS-CoV to humans (e.g., camel breeders).

Although the animal models for evaluating MERS$\mathrm{CoV}$ infection represent progress, they do not recapitulate the pathogenesis of severe human disease. A combination of both small and large animal models should be considered for evaluation of preventive and therapeutic candidates for MERS. Regardless of the chosen model, comparing and interpreting results effectively and reducing discrepancies among laboratories will be crucial for researchers to agree on a set of standards with respect to experimental design, including variables for age of animals, specimen handling, route of administration, type of virus challenge, inoculation schedule, sample collection, and disease scoring algorithms.

\section{Pipeline of MERS-CoV Vaccine and Antibody Technologies}

Building on the experience from the closely related severe acute respiratory syndrome coronavirus (SARS-CoV) (27), researchers have been actively working to understand MERS-CoV genetics to inform vaccine and therapeutic development efforts. They quickly demonstrated that the 
spike (S) protein, a viral surface glycoprotein, was essential for recognition of hDPP4 and viral entry into cells and likely represented a prime target for immunogen design for the development of vaccines and monoclonal antibodies $(18,28,29)$. At the workshop, we reviewed various approaches - all in preclinical development and all based on the $\mathrm{S}$ protein or one of its components, including nanoparticles, subunit proteins and peptides, DNA, various viral vectors, and live attenuated MERS-CoV.

Nanoparticles formed with MERS-CoV S protein, under development by Novavax (Gaithersburg, Maryland, USA), have been shown to induce virus neutralizing antibodies (NAbs) in mice after a single injection; proprietary adjuvants enhance this response (30). Vaccines using antigens expressed from the baculovirus platform developed by Novavax have been evaluated in human subjects in the context of phase I and phase II clinical studies for other infectious diseases without notable vaccine-related safety concerns (31-33).

Portions of the $\mathrm{S}$ protein, specifically the receptorbinding domain $(8,29,34-36)$, are also being developed as subunit vaccines. Jiang noted that these fragments map to a "critical neutralizing region" and induce strong immune responses and NAbs in mouse models $(37,38)$. Moreover, the subunit vaccines have been shown to protect transgenic mice when challenged with MERS-CoV, indicating that vaccines focused on the receptor-binding domain may be sufficient for protective immunity to develop against the virus $(39,40)$.

Several viral vectors, including adenovirus $(41,42)$, modified vaccinia Ankara (MVA) $(43,44)$, and measles virus (45), are also under development by different groups. Various lengths of S protein are being expressed on these platforms and are able to generate antibodies in animals that can neutralize MERS-CoV in vitro and, at least for some vector platforms, also generate cellular immune responses $(43,45)$. For MVA- and measles virus-based vaccines, these responses confer protection in hDPP4-expressing mice $(43,45)$. MVA constructs, which have established safety profiles in humans, have been tested in camels and can induce protective immunity, representing a potential veterinary technology (46). Moreover, on the basis of supportive data from animal studies, these MVA constructs will soon enter clinical trials. Vaccines based on live attenuated viruses historically have been shown to be highly efficacious; they are also safe and generally well tolerated. Enjuanes and others reported to the group the development of 2 engineered MERS-CoV vaccine candidates. One candidate was based on a propagation-defective MERS-CoV strain, and another was a live attenuated virus with 3 safety guards that used a MERS-CoV infectious cDNA clone (47). An inactivated SARS-CoV vaccine was shown to be safe and able to induce NAbs in a phase I trial (48).
DNA vaccines are generally perceived as a safe, stable platform for in vivo antigen expression. A SARS-CoV DNA vaccine, which expresses the SARS-CoV S protein, has been shown to induce NAbs and functional T-cell responses in humans (49). GeneOne (Blue Bell, PA, USA) is developing a proprietary, full-length S protein DNA vaccine candidate that has been shown to induce NAbs and highly functional $\mathrm{T}$ cells in various animal models and protect rhesus macaques from infection after MERS-CoV challenge when the vaccine is administered with electroporation to enhance uptake of the plasmid DNA (50). Concerns remain regarding the immunogenicity of DNA vaccines in humans, although the effects of using therapeutic vaccination strategies for other diseases raise the potential for DNA-only approaches (51). In addition, Modjarrad reported that using a prime-boost format, that a full-length $\mathrm{S}$ protein DNA vaccine, followed by an S-protein boost, can increase NAb titers, reduce the clinical severity of MERS, and increase the durability of protection in macaques (52).

To complement active immunization approaches, researchers are also advancing several prophylactic or therapeutic approaches against MERS-CoV using NAb technologies through preclinical development. Because these NAbs target epitopes of the S protein (or specifically the receptor-binding domain), they can cause precise and potent inhibitory effects on viral entry in small and large animal models (53). The mechanisms of neutralization have been uncovered and are typically mediated by blocking MERSCoV binding to hDPP4 $(22,52,54-56)$. As the supplementary agents of antibodies, the peptidic MERS-CoV fusion inhibitors targeting the conserved region in the $\mathrm{S}$ protein HR1 domain region are highly potent in inhibiting infection of MERS-CoV strains, including those resistant to NAbs. Intranasal administration of the peptides protected hDPP4-transgenic mice from MERS-CoV challenge, suggesting that, alone or in combination with NAbs, these peptides could be used to prevent and treat MERS-CoV infection $(37,39,57)$.

Further characterization of these technologies and the potential for combination approaches are ongoing as investigators tackle questions related to viral escape $(58,59)$. Preliminary results indicate that viruses that evade antibody neutralization have reduced viral fitness, demonstrating that escape can occur but comes at a cost to fitness. Nevertheless, continued investigation and surveillance are warranted. Marasco noted that sequencing of circulating strains will be critical to monitor viral evolution (60), which will only be possible with increased sample- and data-sharing. Ongoing studies related to cross-reactivity with human tissue and the effects of polyclonal and nonneutralizing antibodies are also underway as passive immunotherapy becomes more accepted to prevent and treat MERS-CoV infection. 
Overall, selecting specific technologies and approaches that warrant further development is difficult, given the diversity of models and readouts and the concomitant need for greater standardization in the field. Although each technology presents unique advantages and deficiencies related to desired immunogenicity, safety, durability of protection, need for adjuvant, and manufacturing considerations, some technologies have a long track record in the clinic, which would potentially simplify their development and regulatory pathway. Given the public health urgency, these platforms (or combinations thereof) should be made a priority.

The experience with SARS-CoV offers a sobering lesson: countermeasures that advance on the basis of promising preclinical data may ultimately exacerbate disease in humans. Antibody-dependent enhancement of infectivity has been observed in cell culture in which a human promonocyte cell line is used 61-63). In mice and hamsters vaccinated with a recombinant native full-length SARS$\mathrm{CoV} \mathrm{S}$ protein trimer, serum IgG developed that blocked binding of the S protein to the ACE2 receptor and neutralized SARS-CoV infection in vitro. SARS-CoV entered human B-cell lines in an FcyRII-dependent and ACE2independent fashion, indicating that antibody-dependent enhancement of virus entry is a novel cell entry mechanism of SARS-CoV. Vaccinated animals showed no signs of enhanced lung pathology or hepatitis, and viral load was undetectable or greatly reduced in lungs after challenge with SARS-CoV (64). However, in the presence or absence of adjuvant, vaccination of mice with viruslike particles or inactivated virus induced eosinophilic immunopathologic changes in young and aged mice (65-67). The pulmonary immunopathologic features, on challenge with SARS-CoV, were associated with Th2-type immunopathology with prominent eosinophil infiltration. Although no enhancement of immunopathologic features has been observed in MERS-CoV-vaccinated and -challenged animals, future studies of MERS-CoV vaccines in animals and humans should consider that possibility.

\section{Vaccine Development Considerations for MERS-CoV}

To date, commitment to open communication regarding MERS-CoV vaccine development has been haphazard, and leaders in the field are calling for a new approach that integrates resources to accelerate science and enhance biosecurity. New norms and standards are under development by the World Health Organization (WHO) to streamline sample collection (type, storage and availability, quality control); and information dissemination and publication. Combining resources available in Saudi Arabia, South Korea, the United States, Europe, and beyond to develop countermeasures for MERS-CoV, an "open innovation" paradigm shift can maximize public sector investment, provide robust information for a systems-level approach, and deliver the necessary public health effect that is urgently needed.

The Saudi Arabia MOH, working with Saudi academic institutions, WHO, and other stakeholders, recognizes the crucial role it has to play in defining the public health goals that will guide vaccine development efforts for MERS-CoV $(68,69)$. Researchers, vaccine developers and health authorities must understand how a vaccine is expected to fit into the larger public health strategy to combat MERS (e.g., target populations and vaccination strategies, level of efficacy, safety profile for a vaccine), as well as the pathway to future vaccine testing (e.g., design of efficacy trial), licensure and access. Few vaccine developers in the MERS arena have experience conducting preclinical and clinical research in the Middle East, and the Saudi MOH and Saudi Food and Drug Authority have a valuable role to play in defining the expectations for future clinical studies and in educating developers on the associated regulatory pathway.

\section{Summary}

The potential threat posed by MERS-CoV necessitates a multipronged approach to the development of effective countermeasures. Salient public health messages from the workshop included the following points:

1. Accelerating the development of a vaccine requires a better understanding of MERS-CoV epidemiology, transmission, and pathogenesis in humans and animals. This information will help develop target product profiles for human and veterinary vaccines, which in turn will facilitate planning for efficacy trials and inform development strategies.

2. Because current animal models do not fully reflect hallmarks of severe human disease, a combination of both rodents and nonhuman primate models should be considered in evaluating and developing preventive and therapeutic candidates under standardized conditions.

3. Current vaccine development strategies involve a variety of technology platforms, primarily targeting the MERS-CoV S protein. Given the public health urgency, platforms (or combinations thereof) with an established safety track record in humans should be given priority. Other target species such as dromedary camels should also be considered for the development of veterinary vaccines as a One Health approach.

4. Attention should be paid to lessons learned from SARS-CoV vaccine development efforts, particularly to signs of potential disease enhancement in various animal models. 
5. Therapeutic antibodies are recognized as potentially useful tools in MERS prevention and treatment, but the concern around escape mutants with increased fitness, although concern is not limited to this technology type, warrants continued investigation and surveillance. Such an approach could be considered alone or in combination with vaccine approaches. As supplementary agents, the peptidic fusion inhibitors may be developed as MERS prophylactics and therapeutics.

6. An opportunity exists for greater coordination around specific technology platforms and to ensure that appropriate incentives are considered to stimulate research and development collaboration from academia, industry, nongovernmental organizations, and governments.

7. The Saudi Arabia $\mathrm{MOH}$, working with $\mathrm{WHO}$ and other stakeholders, has a crucial role to play in defining the public health goals that will guide vaccine development efforts.

\section{Next Steps: Establishing a New Paradigm for Collaboration}

Funding agencies, nongovernmental organizations, and companies recognize the need for cooperation and have resolved to formalize a collaborative model. The field recognizes the opportunity to set a precedent for how it collaborates as a global community in the context of an emerging disease, building on lessons learned from the recent international response to the Ebola epidemic. Although still subject to consultation, key components of a partnership(s) were identified, including coordinating funding, sharing samples/data, advancing preclinical models, beginning clinical trials in regions having outbreaks, and standardizing assays and reagents for testing.

Exact partnership structures remain to be determined but should at the very least allow for coordination of activities through frequent, transparent, and open discussions among funding agencies and stakeholders. Future models, including a formalized consortium of players who would make a long-term commitment to advance selected products through development phases, can be contemplated once technologies are evaluated more rigorously. Regardless of the final partnership structure(s), the core of any collaborative strategy should include sharing of data and samples and standardizing laboratory assays to ensure that everyone learns from each other, are able to compare technologies, and ultimately accelerate the development of new solutions.

V.S.M. is supported by the Intramural Research Program of the National Institute of Allergy and Infectious Diseases, US National Institutes of Health.
Dr. Excler is the head of Clinical Development and Regulatory Affairs at the International Vaccine Institute, Seoul, South Korea. He has been working extensively for the past 25 years on the clinical development of an HIV vaccine.

\section{References}

1. Zumla A, Hui DS, Perlman S. Middle East respiratory syndrome. Lancet. 2015;386:995-1007. http://dx.doi.org/10.1016/S01406736(15)60454-8

2. Müller MA, Meyer B, Corman VM, A1-Masri M, Turkestani A, Ritz D, et al. Presence of Middle East respiratory syndrome coronavirus antibodies in Saudi Arabia: a nationwide, crosssectional, serological study. Lancet Infect Dis. 2015;15:559-64. http://dx.doi.org/10.1016/S1473-3099(15)70090-3

3. Ki M. 2015 MERS outbreak in Korea: hospital-to-hospital transmission. Epidemiol Health. 2015;37:e2015033. http://dx.doi.org/10.4178/epih/e2015033

4. Hui DS, Perlman S, Zumla A. Spread of MERS to South Korea and China. Lancet Respir Med. 2015;3:509-10. http://dx.doi.org/10.1016/S2213-2600(15)00238-6

5. Cowling BJ, Park M, Fang VJ, Wu P, Leung GM, Wu JT. Preliminary epidemiological assessment of MERS-CoV outbreak in South Korea, May to June 2015. Euro Surveill. 2015;20:7-13. http://dx.doi.org/10.2807/1560-7917.ES2015.20.25.21163

6. Assiri A, Al-Tawfiq JA, Al-Rabeeah AA, Al-Rabiah FA, Al-Hajjar S, Al-Barrak A, et al. Epidemiological, demographic, and clinical characteristics of 47 cases of Middle East respiratory syndrome coronavirus disease from Saudi Arabia: a descriptive study. Lancet Infect Dis. 2013;13:752-61. http://dx.doi.org/10.1016/S1473-3099(13)70204-4

7. Al-Tawfiq JA, Memish ZA. An update on Middle East respiratory syndrome: 2 years later. Expert Rev Respir Med. 2015;9:327-35. http://dx.doi.org/10.1586/17476348.2015.1027689

8. Du L, Jiang S. Middle East respiratory syndrome: current status and future prospects for vaccine development. Expert Opin Biol Ther. 2015;15:1647-51. http://dx.doi.org/10.1517/14712598.2015. 1092518

9. Khamsi R. MERS vaccines advance, but will humans or camels get the jab? Nat Med. 2015;21:1106. http://dx.doi.org/10.1038/ nm1015-1106

10. Papaneri AB, Johnson RF, Wada J, Bollinger L, Jahrling PB, Kuhn JH. Middle East respiratory syndrome: obstacles and prospects for vaccine development. Expert Rev Vaccines. 2015;14:949-62. http://dx.doi.org/10.1586/14760584.2015.1036033

11. van Doremalen N, Munster VJ. Animal models of Middle East respiratory syndrome coronavirus infection. Antiviral Res. 2015;122:28-38. http://dx.doi.org/10.1016/j.antiviral.2015.07.005

12. Raj VS, Smits SL, Provacia LB, van den Brand JM, Wiersma L, Ouwendijk WJ, et al. Adenosine deaminase acts as a natural antagonist for dipeptidyl peptidase 4-mediated entry of the Middle East respiratory syndrome coronavirus. J Virol. 2014;88:1834-8. http://dx.doi.org/10.1128/JVI.02935-13

13. Coleman CM, Matthews KL, Goicochea L, Frieman MB. Wild-type and innate immune-deficient mice are not susceptible to the Middle East respiratory syndrome coronavirus. J Gen Virol. 2014;95:408-12. http://dx.doi.org/10.1099/vir.0.060640-0

14. de Wit E, Prescott J, Baseler L, Bushmaker T, Thomas T, Lackemeyer MG, et al. The Middle East respiratory syndrome coronavirus (MERS-CoV) does not replicate in Syrian hamsters. PLoS ONE. 2013;8:e69127. http://dx.doi.org/10.1371/ journal.pone.0069127

15. Ohnuma K, Dang NH, Morimoto C. Revisiting an old acquaintance: CD26 and its molecular mechanisms in T cell function. Trends Immunol. 2008;29:295-301. http://dx.doi.org/10.1016/j.it.2008.02.010 
16. Cockrell AS, Peck KM, Yount BL, Agnihothram SS, Scobey T, Curnes NR, et al. Mouse dipeptidyl peptidase 4 is not a functional receptor for Middle East respiratory syndrome coronavirus infection. J Virol. 2014;88:5195-9. http://dx.doi.org/10.1128/JVI.03764-13

17. van Doremalen N, Miazgowicz KL, Milne-Price S, Bushmaker T, Robertson S, Scott D, et al. Host species restriction of Middle East respiratory syndrome coronavirus through its receptor, dipeptidyl peptidase 4. J Virol. 2014;88:9220-32. http://dx.doi.org/10.1128/ JVI.00676-14

18. Raj VS, Mou H, Smits SL, Dekkers DH, Muller MA, Dijkman R, et al. Dipeptidyl peptidase 4 is a functional receptor for the emerging human coronavirus-EMC. Nature. 2013;495:251-4. http://dx.doi.org/10.1038/nature12005

19. Lu G, Hu Y, Wang Q, Qi J, Gao F, Li Y, et al. Molecular basis of binding between novel human coronavirus MERS-CoV and its receptor CD26. Nature. 2013;500:227-31.

http://dx.doi.org/10.1038/nature12328

20. Agrawal AS, Garron T, Tao X, Peng BH, Wakamiya M, Chan TS, et al. Generation of a transgenic mouse model of Middle East respiratory syndrome coronavirus infection and disease. J Virol. 2015;89:3659-70. http://dx.doi.org/10.1128/ JVI.03427-14

21. Zhao J, Li K, Wohlford-Lenane C, Agnihothram SS, Fett C, Zhao J, et al. Rapid generation of a mouse model for Middle East respiratory syndrome. Proc Natl Acad Sci U S A. 2014;111:4970-5. http://dx.doi.org/10.1073/pnas.1323279111

22. Pascal KE, Coleman CM, Mujica AO, Kamat V, Badithe A, Fairhurst J, et al. Pre- and postexposure efficacy of fully human antibodies against Spike protein in a novel humanized mouse model of MERS-CoV infection. Proc Natl Acad Sci U S A. 2015;112:8738-43. http://dx.doi.org/10.1073/pnas.1510830112

23. Munster VJ, de Wit E, Feldmann H. Pneumonia from human coronavirus in a macaque model. N Engl J Med. 2013;368:1560-2. http://dx.doi.org/10.1056/NEJMc1215691

24. Johnson RF, Via LE, Kumar MR, Cornish JP, Yellayi S, Huzella L, et al. Intratracheal exposure of common marmosets to MERS-CoV Jordan-n3/2012 or MERS-CoV EMC/2012 isolates does not result in lethal disease. Virology. 2015;485:422-30. http://dx.doi.org/10.1016/j.virol.2015.07.013

25. Falzarano D, de Wit E, Feldmann F, Rasmussen AL, Okumura A, Peng X, et al. Infection with MERS-CoV causes lethal pneumonia in the common marmoset. PLoS Pathog. 2014;10:e1004250. http://dx.doi.org/10.1371/journal.ppat.1004250

26. Adney DR, van Doremalen N, Brown VR, Bushmaker T, Scott D, de Wit E, et al. Replication and shedding of MERS-CoV in upper respiratory tract of inoculated dromedary camels. Emerg Infect Dis. 2014;20:1999-2005. http://dx.doi.org/10.3201/eid2012.141280

27. Du L, He Y, Zhou Y, Liu S, Zheng BJ, Jiang S. The spike protein of SARS-CoV - a target for vaccine and therapeutic development. Nat Rev Microbiol. 2009;7:226-36. http://dx.doi.org/10.1038/nrmicro2090

28. Buchholz UJ, Bukreyev A, Yang L, Lamirande EW, Murphy BR, Subbarao K, et al. Contributions of the structural proteins of severe acute respiratory syndrome coronavirus to protective immunity. Proc Natl Acad Sci U S A. 2004;101:9804-9. http://dx.doi.org/10.1073/pnas.0403492101

29. Du L, Zhao G, Kou Z, Ma C, Sun S, Poon VK, et al. Identification of a receptor-binding domain in the $\mathrm{S}$ protein of the novel human coronavirus Middle East respiratory syndrome coronavirus as an essential target for vaccine development. J Virol. 2013;87:9939-42. http://dx.doi.org/10.1128/JVI.01048-13

30. Coleman CM, Liu YV, Mu H, Taylor JK, Massare M, Flyer DC, et al. Purified coronavirus spike protein nanoparticles induce coronavirus neutralizing antibodies in mice. Vaccine. 2014; 32:3169-74. http://dx.doi.org/10.1016/j. vaccine.2014.04.016
31. Fries LF, Smith GE, Glenn GM. A recombinant viruslike particle influenza A (H7N9) vaccine. N Engl J Med. 2013;369:2564-6. http://dx.doi.org/10.1056/NEJMc1313186

32. Glenn GM, Fries LF, Thomas DN, Smith G, Kpamegan E, $\mathrm{Lu} \mathrm{H}$, et al. A randomized, blinded, controlled, dose-ranging study of a respiratory syncytial virus recombinant fusion (f) nanoparticle vaccine in healthy women of childbearing age. J Infect Dis. 2016;213:411-22. http://dx.doi.org/10.1093/infdis/jiv406

33. Glenn GM, Smith G, Fries L, Raghunandan R, Lu H, Zhou B, et al. Safety and immunogenicity of a $\mathrm{Sf} 9$ insect cell-derived respiratory syncytial virus fusion protein nanoparticle vaccine. Vaccine. 2013;31:524-32. http://dx.doi.org/10.1016/j. vaccine.2012.11.009

34. Lan J, Deng Y, Chen H, Lu G, Wang W, Guo X, et al. Tailoring subunit vaccine immunity with adjuvant combinations and delivery routes using the Middle East respiratory coronavirus (MERS-CoV) receptor-binding domain as an antigen. PLoS ONE. 2014;9:e112602. http://dx.doi.org/10.1371/journal. pone. 0112602

35. Lan J, Yao Y, Deng Y, Chen H, Lu G, Wang W, et al. Recombinant receptor binding domain protein induces partial protective immunity in rhesus macaques against Middle East respiratory syndrome coronavirus challenge. EBioMedicine. 2015;2:1438-46. http://dx.doi.org/10.1016/j.ebiom.2015.08.031

36. Tang J, Zhang N, Tao X, Zhao G, Guo Y, Tseng CT, et al. Optimization of antigen dose for a receptor-binding domain-based subunit vaccine against MERS coronavirus. Hum Vaccin Immunother. 2015;11:1244-50. http://dx.doi.org/10.1080/2164551 5.2015 .1021527

37. Channappanavar R, Lu L, Xia S, Du L, Meyerholz DK, Perlman S, et al. Protective effect of intranasal regimens containing peptidic Middle East respiratory syndrome coronavirus fusion inhibitor against MERS-CoV infection. J Infect Dis. 2015;212:1894-903. http://dx.doi.org/10.1093/infdis/jiv325

38. Du L, Zhao G, Yang Y, Qiu H, Wang L, Kou Z, et al. A conformation-dependent neutralizing monoclonal antibody specifically targeting receptor-binding domain in Middle East respiratory syndrome coronavirus spike protein. J Virol. 2014; 88:7045-53. http://dx.doi.org/10.1128/JVI.00433-14

39. Tao X, Garron T, Agrawal AS, Algaissi A, Peng BH, Wakamiya M, et al. Characterization and demonstration of value of a lethal mouse model of Middle East respiratory syndrome coronavirus infection and disease. J Virol. 2016;90:57-67. http://dx.doi.org/10.1128/ JVI.02009-15

40. Zhang N, Channappanavar R, Ma C, Wang L, Tang J, Garron T, et al. Identification of an ideal adjuvant for receptor-binding domain-based subunit vaccines against Middle East respiratory syndrome coronavirus. Cell Mol Immunol. 2016;13:180-90. http://dx.doi.org/10.1038/cmi.2015.03

41. Guo X, Deng Y, Chen H, Lan J, Wang W, Zou X, et al. Systemic and mucosal immunity in mice elicited by a single immunization with human adenovirus type 5 or 41 vector-based vaccines carrying the spike protein of Middle East respiratory syndrome coronavirus. Immunology. 2015;145:476-84. http://dx.doi.org/10.1111/imm.12462

42. Kim E, Okada K, Kenniston T, Raj VS, AlHajri MM, Farag EA, et al. Immunogenicity of an adenoviral-based Middle East respiratory syndrome coronavirus vaccine in BALB/c mice. Vaccine. 2014;32:5975-82. http://dx.doi.org/10.1016/j.vaccine.2014.08.058

43. Volz A, Kupke A, Song F, Jany S, Fux R, Shams-Eldin H, et al. Protective efficacy of recombinant modified vaccinia virus Ankara delivering Middle East respiratory syndrome coronavirus spike glycoprotein. J Virol. 2015;89:8651-6. http://dx.doi.org/10.1128/ JVI.00614-15

44. Song F, Fux R, Provacia LB, Volz A, Eickmann M, Becker S, et al. Middle East respiratory syndrome coronavirus spike protein 
delivered by modified vaccinia virus Ankara efficiently induces virus-neutralizing antibodies. J Virol. 2013;87:11950-4. http://dx.doi.org/10.1128/JVI.01672-13

45. Malczyk AH, Kupke A, Prufer S, Scheuplein VA, Hutzler S, Kreuz D, et al. A highly immunogenic and protective MERScoronavirus vaccine based on recombinant MV vaccine platform. J Virol. 2015;89:11654-67. http://dx.doi.org/10.1128/JVI.01815-15

46. Haagmans BL, van den Brand JM, Raj VS, Volz A, Wohlsein P, Smits SL, et al. An orthopoxvirus-based vaccine reduces virus excretion after MERS-CoV infection in dromedary camels. Science. 2016;351:77-81. http://dx.doi.org/10.1126/science.aad1283

47. Almazán F, DeDiego ML, Sola I, Zuniga S, Nieto-Torres JL, Marquez-Jurado S, et al. Engineering a replication-competent, propagation-defective Middle East respiratory syndrome coronavirus as a vaccine candidate. MBio. 2013;4:e0650-13. http://dx.doi.org/10.1128/mBio.00650-13

48. Lin JT, Zhang JS, Su N, Xu JG, Wang N, Chen JT, et al. Safety and immunogenicity from a phase I trial of inactivated severe acute respiratory syndrome coronavirus vaccine. Antivir Ther. 2007;12:1107-13.

49. Martin JE, Louder MK, Holman LA, Gordon IJ, Enama ME, Larkin BD, et al. A SARS DNA vaccine induces neutralizing antibody and cellular immune responses in healthy adults in a Phase I clinical trial. Vaccine. 2008;26:6338-43. http://dx.doi.org/10.1016/j.vaccine.2008.09.026

50. Muthumani K, Falzarano D, Reuschel EL, Tingey C, Flingai S, Villarreal DO, et al. A synthetic consensus anti-spike protein DNA vaccine induces protective immunity against Middle East respiratory syndrome coronavirus in nonhuman primates. Sci Transl Med. 2015;7:301ra132. http://dx.doi.org/10.1126/ scitranslmed.aac7462

51. Trimble CL, Morrow MP, Kraynyak KA, Shen X, Dallas M, Yan J, et al. Safety, efficacy, and immunogenicity of VGX-3100, a therapeutic synthetic DNA vaccine targeting human papillomavirus 16 and 18 E6 and E7 proteins for cervical intraepithelial neoplasia 2/3: a randomised, double-blind, placebo-controlled phase $2 \mathrm{~b}$ trial. Lancet. 2015;386:2078-88. http://dx.doi.org/10.1016/S01406736(15)00239-1

52. Wang L, Shi W, Joyce MG, Modjarrad K, Zhang Y, Leung K, et al. Evaluation of candidate vaccine approaches for MERS-CoV. Nat Commun. 2015;6:7712. http://dx.doi.org/10.1038/ncomms8712

53. Tang XC, Marasco WA. Human neutralizing antibodies against MERS coronavirus: implications for future immunotherapy. Immunotherapy. 2015;7:591-4. http://dx.doi.org/10.2217/imt.15.33

54. Jiang L, Wang N, Zuo T, Shi X, Poon KM, Wu Y, et al. Potent neutralization of MERS-CoV by human neutralizing monoclonal antibodies to the viral spike glycoprotein. Sci Transl Med. 2014;6:234ra59.

55. Ying T, Du L, Ju TW, Prabakaran P, Lau CC, Lu L, et al. Exceptionally potent neutralization of Middle East respiratory syndrome coronavirus by human monoclonal antibodies. J Virol. 2014;88:7796-805. http://dx.doi.org/10.1128/JVI.00912-14

56. Ying T, Prabakaran P, Du L, Shi W, Feng Y, Wang Y, et al. Junctional and allele-specific residues are critical for MERS-CoV neutralization by an exceptionally potent germline-like antibody. Nat Commun. 2015;6:8223. http://dx.doi.org/10.1038/ncomms9223

57. Lu L, Liu Q, Zhu Y, Chan KH, Qin L, Li Y, et al. Structure-based discovery of Middle East respiratory syndrome coronavirus fusion inhibitor. Nat Commun. 2014;5:3067. http://dx.doi.org/10.1038/ ncomms4067

58. Sui J, Deming M, Rockx B, Liddington RC, Zhu QK, Baric RS, et al. Effects of human anti-spike protein receptor binding domain antibodies on severe acute respiratory syndrome coronavirus neutralization escape and fitness. J Virol. 2014;88:13769-80. http://dx.doi.org/10.1128/JVI.02232-14

59. Rani M, Bolles M, Donaldson EF, Van Blarcom T, Baric R, Iverson B, et al. Increased antibody affinity confers broad in vitro protection against escape mutants of severe acute respiratory syndrome coronavirus. J Virol. 2012;86:9113-21. http://dx.doi.org/10.1128/JVI.00233-12

60. Tang XC, Agnihothram SS, Jiao Y, Stanhope J, Graham RL, Peterson EC, et al. Identification of human neutralizing antibodies against MERS-CoV and their role in virus adaptive evolution. Proc Natl Acad Sci U S A. 2014;111:E2018-26. http://dx.doi.org/10.1073/pnas.1402074111

61. Jaume M, Yip MS, Cheung CY, Leung HL, Li PH, Kien F, et al. Anti-severe acute respiratory syndrome coronavirus spike antibodies trigger infection of human immune cells via a $\mathrm{pH}$ - and cysteine protease-independent $\mathrm{F} c \gamma \mathrm{R}$ pathway. J Virol. 2011;85:10582-97. http://dx.doi.org/10.1128/JVI.00671-11

62. Jaume M, Yip MS, Kam YW, Cheung CY, Kien F, Roberts A, et al. SARS CoV subunit vaccine: antibody-mediated neutralisation and enhancement. Hong Kong Med J. 2012;18 (Suppl 2):31-6.

63. Wang SF, Tseng SP, Yen CH, Yang JY, Tsao CH, Shen CW, et al. Antibody-dependent SARS coronavirus infection is mediated by antibodies against spike proteins. Biochem Biophys Res Commun. 2014;451:208-14. http://dx.doi.org/10.1016/j.bbrc.2014.07.090

64. Kam YW, Kien F, Roberts A, Cheung YC, Lamirande EW, Vogel $\mathrm{L}$, et al. Antibodies against trimeric $\mathrm{S}$ glycoprotein protect hamsters against SARS-CoV challenge despite their capacity to mediate FcgammaRII-dependent entry into B cells in vitro. Vaccine. 2007;25:729-40. http://dx.doi.org/10.1016/j.vaccine.2006.08.011

65. Bolles M, Deming D, Long K, Agnihothram S, Whitmore A, Ferris M, et al. A double-inactivated severe acute respiratory syndrome coronavirus vaccine provides incomplete protection in mice and induces increased eosinophilic proinflammatory pulmonary response upon challenge. J Virol. 2011;85:12201-15. http://dx.doi.org/10.1128/JVI.06048-11

66. Tseng CT, Sbrana E, Iwata-Yoshikawa N, Newman PC, Garron T, Atmar RL, et al. Immunization with SARS coronavirus vaccines leads to pulmonary immunopathology on challenge with the SARS virus. PLoS ONE. 2012;7:e35421. http://dx.doi.org/10.1371/ journal.pone. 0035421

67. Iwata-Yoshikawa N, Uda A, Suzuki T, Tsunetsugu-Yokota Y, Sato Y, Morikawa S, et al. Effects of toll-like receptor stimulation on eosinophilic infiltration in lungs of BALB/c mice immunized with UV-inactivated severe acute respiratory syndrome-related coronavirus vaccine. J Virol. 2014;88:8597-614. http://dx.doi.org/10.1128/JVI.00983-14

68. Hotez PJ, Herricks JR. Impact of the neglected tropical diseases on human development in the Organisation of Islamic Cooperation Nations. PLoS Negl Trop Dis. 2015;9:e0003782. http://dx.doi.org/10.1371/journal.pntd.0003782

69. Hotez PJ. Vaccine science diplomacy: expanding capacity to prevent emerging and neglected tropical diseases arising from Islamic State (IS)-held territories. PLoS Negl Trop Dis. 2015;9:e0003852. http://dx.doi.org/10.1371/journal.pntd.0003852

Address for correspondence: Jean-Louis Excler, International Vaccine Institute, SNU Research Park, 1 Gwanak-ro, Gwanak-gu, Seoul, South Korea; email: JeanLouis.Excler@ivi.int 